\title{
Synthesis and Characterization of $\mathrm{LaNiO}_{3}, \mathrm{LaNi}_{(1-x)} \mathrm{Fe}_{\mathrm{x}} \mathrm{O}_{3}$ and $\mathrm{LaNi}_{(1-x)} \mathrm{Co}_{\mathrm{x}} \mathrm{O}_{3}$ Perovskite Oxides for Catalysis Application
}

\author{
Sania Maria de Lima, José Mansur Assaf* \\ Departamento de Engenharia Química, Universidade Federal de São Carlos, \\ Rodovia Washington Luís Km 235, 13565-905 São Carlos - SP, Brazil
}

Received: September 27, 2001; Revised: July 10, 2002

\begin{abstract}
Mixed metal oxides with perovskite-type structure show a great potential to be used in catalysis, electrocatalysis and electronic ceramics. Perovskites oxides catalysts with the composition $\mathrm{LaNiO}_{3}, \mathrm{LaNi}_{(1-x)} \mathrm{Fe}_{\mathrm{x}} \mathrm{O}_{3}$ and $\mathrm{LaNi}_{(1-\mathrm{x})} \mathrm{Co}_{\mathrm{x}} \mathrm{O}_{3}(\mathrm{x}=0.4$ and 0.7$)$ have been synthesized by the precipitation method to be used in the methane reforming to produce hydrogen and synthesis gas. The compounds were characterized by X-ray diffraction, thermogravimetric and differential thermal analysis, inductively coupled plasma atomic emission spectroscopy, surface area measurements, energy dispersive X-ray spectrometry coupled to scanning electron microscopy and temperature programmed reduction. The results showed that a suitable combination of the preparation method with calcination variables (time and temperature) could result in oxides with the desired structure and with important properties at the application point of view in heterogeneous catalysis.
\end{abstract}

Keywords: $\mathrm{LaNiO}_{3}$, Perovskite, precipitation, catalysis

\section{Introduction}

The methane steam and $\mathrm{CO}_{2}$ reforming are endothermic processes for the manufacture of syngas and hydrogen with molar ratio $\mathrm{H}_{2} / \mathrm{CO}$ between 1 and $3^{1}$. They are used in industry for the methanol, Fischer-Tropsch and ammonia synthesis. The first detailed study of the catalytic reaction between steam and methane was published in $1924^{2}$. It was subsequently found out that many metals including nickel, cobalt, iron and the platinum group metals could catalyze these reactions. These are the most important industrial processes for the production of carbon monoxide and hydrogen $^{3}$.

Ni catalysts, a cheap and high active metal, have been applied in methane reforming for the production of hydrogen. However, it tends to lose the catalytic activity because of coke formation ${ }^{4}$. It is possible to modify this behavior by adding oxides of alkaline earth and alkaline metals with high basicity ${ }^{5-7}$. From this point of view, Ni-containing perovskites-type oxides are an alternative of great interest once it has properties that can be modified by changes in the chemical composition ${ }^{8}$. Meadowcroft first reported the use of perovskite-type oxides as catalysts in $1970^{9}$ for the electrochemical reduction of oxygen. Soon after that,
Voorhoeve et al. ${ }^{10}$ reported the high catalytic activity of perovskite oxides for heterogeneous oxidation. These studies triggered many other works.

The perovskite lattice can accommodate multiple cationic substitutions with only small changes and in consequence, several properties of the solid, such as sintering and catalytic performance can be modified. Those oxides are represented by the general formula $\mathrm{ABO}_{3}$ in which $\mathrm{A}$ ions can be rare earth, alkaline earth and alkali that fit into dodecahedral site of the framework, and the B ions can be $3 \mathrm{~d}, 4 \mathrm{~d}$ and $5 \mathrm{~d}$ transitional metal ions which occupy the octahedral sites ${ }^{11}$. These solids are resistant to high temperatures, they are mechanically and chemically stable in the reaction medium and show interesting dielectric and conductor properties ${ }^{8}$.

On $\mathrm{Al}_{2} \mathrm{O}_{3}$, a traditional support used for nickel catalysts, the reduction from free or segregated $\mathrm{NiO}$ to metallic nickel occurs at a relatively low temperature (lower than $\left.450{ }^{\circ} \mathrm{C}\right)^{12}$. The addition of $\mathrm{La}_{2} \mathrm{O}_{3}$ stabilizes this structure and the interactions created by the formation of bonds between Ni oxide and the rare earth allows the increase of the reduction temperature of nickel oxide. However, particularly for $\mathrm{LaNiO}_{3}$, the thermal stability is low under reductive atmos-

*e-mail:mansur@power.ufscar.br 
phere $^{13}$. Slagtern et al. ${ }^{14,15}$ studied the reduction properties of substituted perovskite with a non-reductive element and suggested that a progressive reduction of the structure from mixed oxides occurs where $\mathrm{Ni}$ is stabilized. Slagtern e Olsbye $^{16}$ studied the addition of a third metal into the perovskite structure to stabilize the catalytic system in reductive atmosphere and to limit the metal particle growth.

Aiming at the stabilization of perovskite structure under reductive atmosphere, this work has studied the effect of the preparation variables of $\mathrm{LaNiO}_{3}, \mathrm{LaNi}_{(1-\mathrm{x})} \mathrm{Fe}_{\mathrm{x}} \mathrm{O}_{3}$ and $\mathrm{LaNi}_{(1-\mathrm{x})} \mathrm{Co}_{\mathrm{x}} \mathrm{O}_{3}(\mathrm{x}=0.4$ and 0.7$)$ perovskite-type oxides for potential applications in the methane reforming reactions. The elements $\mathrm{La}, \mathrm{Ni}, \mathrm{Fe}, \mathrm{Co}$ were chosen according to the literature. Lanthanum is a rare earth that stabilizes the structure and prevents coke formation, nickel is very active in the methane reforming reactions and the metals $\mathrm{Fe}$ and $\mathrm{Co}$ present ionic radius close to that of $\mathrm{Ni}$.

\section{Experimental}

The $\mathrm{LaNiO}_{3}, \mathrm{LaNi}_{(1-\mathrm{x})} \mathrm{Fe}_{\mathrm{x}} \mathrm{O}_{3}$ and $\mathrm{LaNi}_{(1-\mathrm{x})} \mathrm{Co}_{\mathrm{x}} \mathrm{O}_{3}(\mathrm{x}=0.4$ e 0.7$)$ perovskite oxides were prepared by precipitation employing two methods. In method 1 , an aqueous solution of sodium carbonate (used in excess) was slowly added to the solution containing equimolar quantities of nitrates of La (Riedel-deHaën) and Ni (Aldrich), with Fe or Co nitrates (Merck) in the required amounts. The precipitate formed was washed thoroughly with approximately 2.01 of distilled water and then filtered and dried at $60^{\circ} \mathrm{C}$ for $20 \mathrm{~h}$. After drying, the filtered precipitate was heated for $3 \mathrm{~h}$ at $550{ }^{\circ} \mathrm{C}$ in air and calcined in different conditions at $800{ }^{\circ} \mathrm{C}$ for $5 \mathrm{~h}$ or at $900^{\circ} \mathrm{C}$ for $5 \mathrm{~h}, 10 \mathrm{~h}$ and $15 \mathrm{~h}$. In method 2 , the solution of nitrates was quickly added to the solution of sodium carbonate. The washing, drying and calcination processes were similar to the ones in the previous method.

The catalysts were characterized by X-ray powder diffraction (XRD) on a Siemens diffractometer D-5005 by using nickel-filtered $\mathrm{CuK}_{\alpha}$ radiation for the determination of the final structure. Derivative thermogravimetric and differential thermal analyses (DTGA and DTA) were performed in an analyzer TA Instruments - SDT 2960 in order to determine phase changes and loss of mass during the calcination process. The amounts of $\mathrm{La}, \mathrm{Ni}, \mathrm{Fe}$ and $\mathrm{Co}$ in the compounds were measured by inductively coupled plasma atomic emission spectroscopy (ICP-AES) on a spectrometer VISTA - VARIAN. The surface area of the perovskite was measured by $\mathrm{N}_{2}$ adsorption - BET (BrunauerEmmett-Teller) method in Quantachrome NOVA 1200. Scanning electron microscopy (SEM) was performed in order to determine the particle size and morphology of the perovskite by using a STEREOSCAN 440 - LEO microscope. Energy dispersive X-ray spectrometry (EDS) on OXFORD EXL II analyzer was performed coupled with the
SEM to gather information about the distribution of single elements in the perovskite phase. Temperature programmed reduction (TPR) was carried out on Micromeritics Pulse Chemisorb 2705 using $30 \mathrm{mg}$ of sample placed in a Ushaped quartz reactor with heating rate of $10{ }^{\circ} \mathrm{C} \cdot \mathrm{min}^{-1}$ at room temperature of up to $1000{ }^{\circ} \mathrm{C}$. The samples were preheated before analysis with $\mathrm{He}$, flow rate of $30 \mathrm{ml} . \mathrm{min}^{-1}$ for $1 \mathrm{~h}$ at $250{ }^{\circ} \mathrm{C}$, to eliminate adsorbed water. The reductive gas used was a mixture of $5 \% \mathrm{H}_{2} / \mathrm{N}_{2}$ with total flow of $30 \mathrm{ml} \cdot \mathrm{min}^{-1}$. This technique aims at obtaining information on the reduction of the oxides species. During the analysis the flow of a reductive gas in the sample takes place, under controlled conditions of flow rate and pressure, while the temperature is increased evenly. The amount of hydrogen consumed during the reduction of the oxidized species is measured by a thermal conductivity detector, thus obtaining a qualitative vision of the reduction of the sample and informing the number of reduced species.

\section{Results and discussion}

The methods 1 and 2 were employed to prepare the perovskite samples that were calcined at $900{ }^{\circ} \mathrm{C}$ for $10 \mathrm{~h}$. The XRD diagrams of the oxides prepared according to method 1 showed the formation of other compounds such as $\mathrm{NiO}$ and $\mathrm{La}_{2} \mathrm{O}_{3}$ besides the perovskite structure, whereas in method 2 the perovskite structure was the only phase observed (Fig. 1). In method 1, as a consequence of the slow addition of the solution of carbonate over the nitrates solutions, a selective precipitation could be occurring, where the lanthanum carbonate, precipitating in lower $\mathrm{pH}$, would be formed first and the precipitation of the nickel carbonate would only have occurred after the end of first precipita-

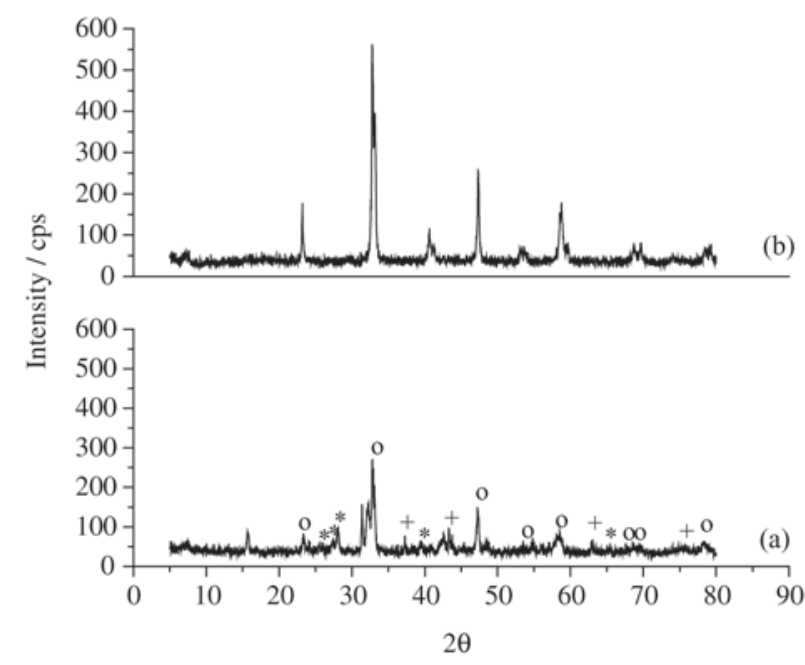

Figure 1. XRD diagrams of $\mathrm{LaNiO}_{3}$ perovskite calcined at $900{ }^{\circ} \mathrm{C}$ for 10 h. a) method 1 ; b) method 2. o: $\mathrm{LaNiO}_{3} ; *: \mathrm{La}_{2} \mathrm{O}_{3} ;+$ : NiO. 
tion, when the $\mathrm{pH}$ reached higher values. As this precipitation was performed slow and selectively, it resulted in larger solid particles of homogeneous composition, preventing the subsequent reaction in the solid state for formation of the perovskite structure. This hypothesis is supported by SEM/ EDS analysis of the precursors of $\mathrm{LaNiO}_{3}$ perovskite oxides prepared according to the two methods (Fig. 2).

The results in Fig. 2 clearly show that the structure obtained by method 1 is quite heterogeneous, with well-arranged La rich particles and with other regions where the amounts of $\mathrm{Ni}$ and $\mathrm{La}$ are closer to the ideal ones for the synthesis of perovskite oxides.

As well-defined particles, with different shapes from the expected ones for perovskite, were observed, a new EDS analysis was done, scanning only one particle. The selected particle is indicated in the micrograph presented in Fig. 3a.
An amount of La observed was greater than the amount of $\mathrm{Ni}$ (Fig. 3b), confirming the presence of lanthanum oxide separated from the structure after calcination.

Aiming at obtaining solids with homogeneous composition and perovskite structure as the only phase, the other catalysts were prepared by method 2 only.

The amounts of metals in the perovskite oxides prepared by method 2 , determined by plasma spectroscopy, presents a good balance between the theoretical and experimental values. Those results are shown in Table 1.

The XRD diagrams of $\mathrm{LaNiO}_{3}, \mathrm{LaNi}_{(1-\mathrm{x})} \mathrm{Fe}_{\mathrm{x}} \mathrm{O}_{3}$ and $\mathrm{LaNi}_{(1-x)} \mathrm{Co}_{\mathrm{x}} \mathrm{O}_{3}(\mathrm{x}=0.4$ and 0.7$)$ oxides were compared with the position and relative intensity patterns of the pure materials ${ }^{18}$. In each case the formation of a single phase with the perovskite structure was confirmed for the oxides prepared by method 2. The diagrams for the $\mathrm{LaNiO}_{3}$ structure with
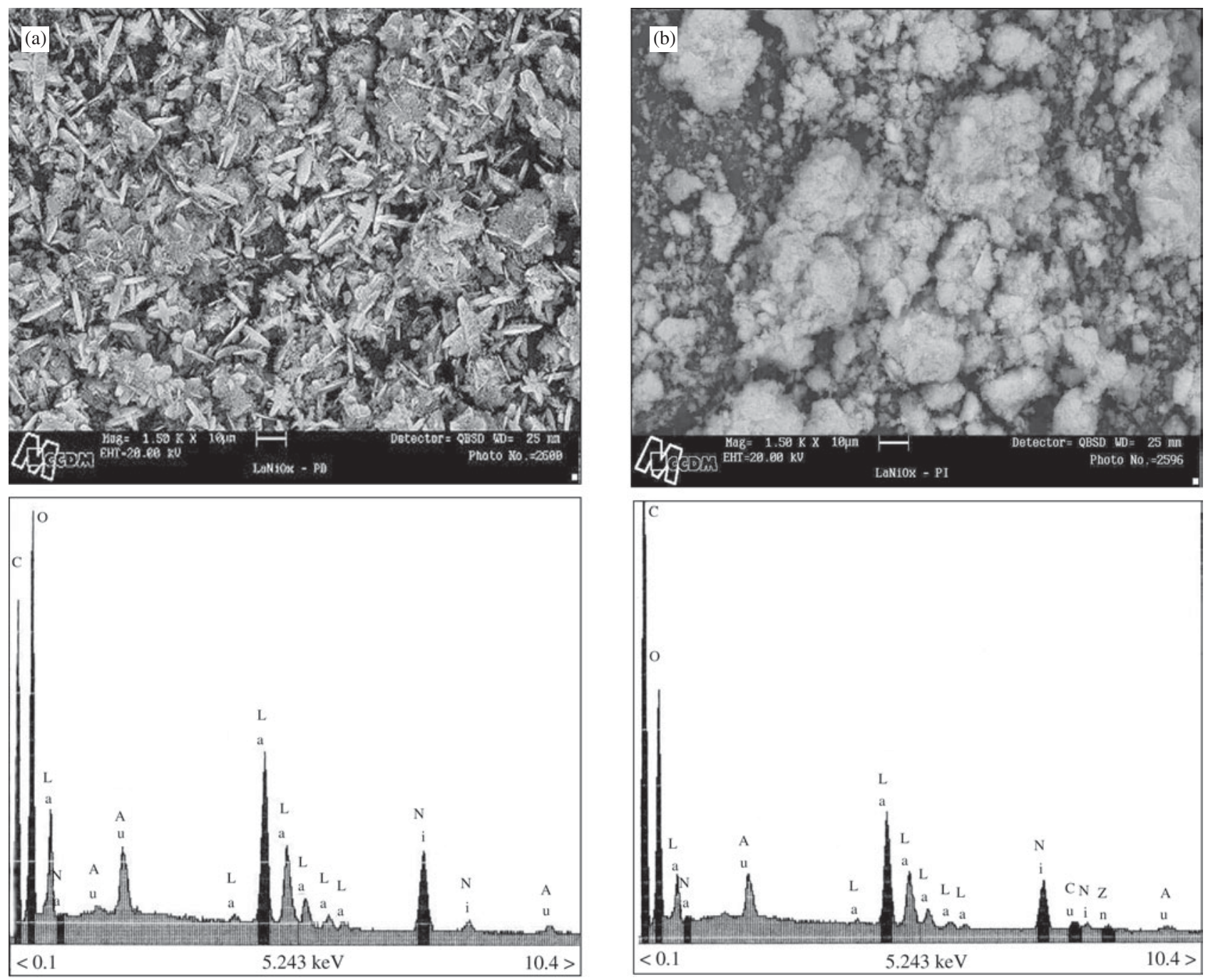

Figure 2. Scanning electron microscopy coupled to energy dispersive X-ray spectrometry for $\mathrm{LaNiO}_{3}$ precursor. a) method 1 , b) method 2 . 

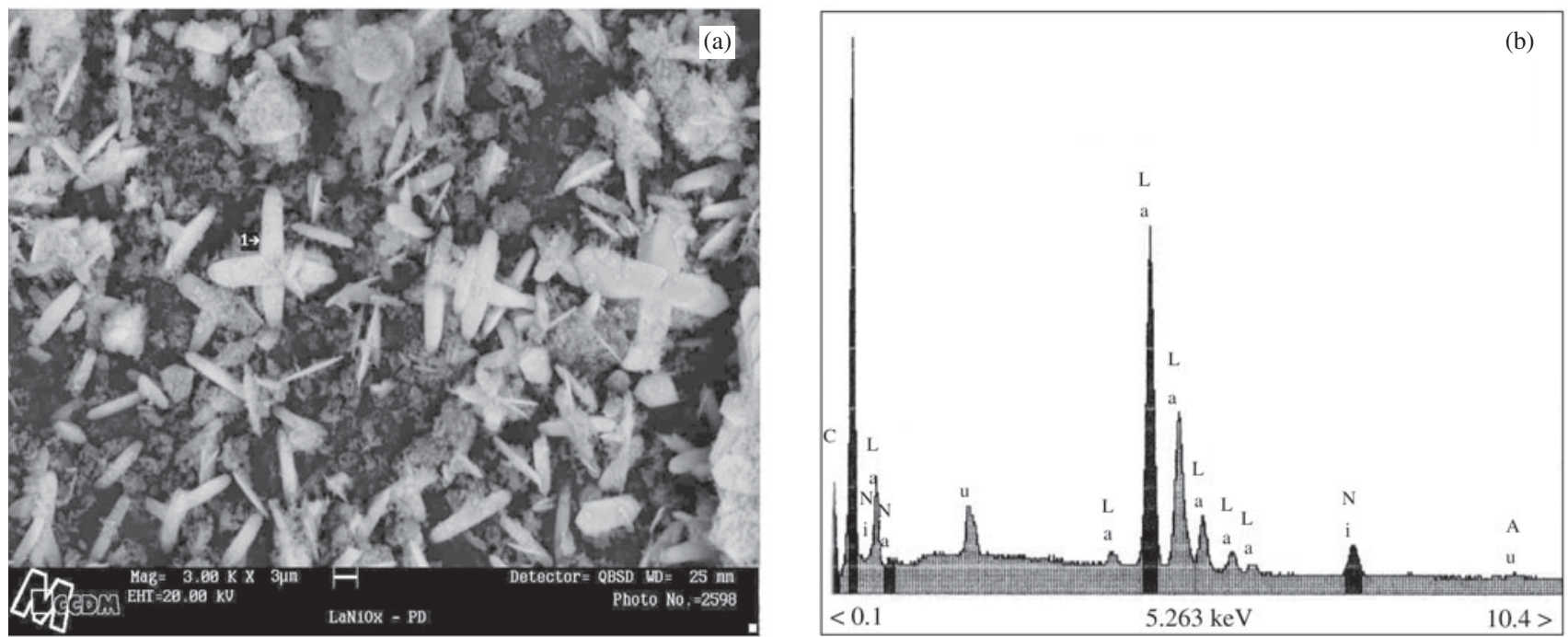

Figure 3. $\mathrm{LaNiO}_{3}$ precursor - method 1. a) Scanning electron microscopy micrograph of particle 1, b) energy dispersive X-ray spectrometry of particle 1 .

Table 1. Inductively coupled plasma atomic emission spectroscopy analyses.

\begin{tabular}{lcccccccc}
\hline $\begin{array}{l}\text { Perovskite } \\
\text { composition }\end{array}$ & \multicolumn{9}{c}{ Theoretical \% } & \multicolumn{5}{c}{ Real \% } \\
\hline & $\mathrm{La}$ & $\mathrm{Ni}$ & $\mathrm{Fe}$ & $\mathrm{Co}$ & $\mathrm{La}$ & $\mathrm{Ni}$ & $\mathrm{Fe}$ & $\mathrm{Co}$ \\
$\mathrm{LaNiO}_{3}$ & 56.55 & 23.91 & - & - & 53.25 & 23.26 & - & - \\
$\mathrm{LaNi}_{0.6} \mathrm{Fe}_{0.4} \mathrm{O}_{3}$ & 56.87 & 14.42 & 9.06 & - & 50.25 & 13.33 & 8.09 & - \\
$\mathrm{LaNi}_{0.3} \mathrm{Fe}_{0.7} \mathrm{O}_{3}$ & 57.10 & 7.24 & 15.93 & - & 50.80 & 6.70 & 15.09 & - \\
$\mathrm{LaNi}_{0.6} \mathrm{Co}_{0.4} \mathrm{O}_{3}$ & 56.52 & 14.33 & - & 9.61 & 52.50 & 14.10 & - & 9.29 \\
$\mathrm{LaNi}_{0.3} \mathrm{Co}_{0.7} \mathrm{O}_{3}$ & 56.50 & 7.16 & - & 16.81 & 50.93 & 7.63 & - & 18.05 \\
\hline
\end{tabular}

varied calcination time and temperature are shown in Fig. 4. At $800{ }^{\circ} \mathrm{C}$, the perovskite structure was obtained and by increasing the temperature and the time of calcination, the structure was closer to the standard, showing that a greater severity in the calcination conditions makes it closer to the standard phase with hexagonal structure. Rakshit and Gopalakrishnan $(1994)^{19}$ have synthesized $\mathrm{LaNiO}_{3}$ perovskites and observed the perovskite structure as the only phase, with cubic structure, for samples calcined at $800{ }^{\circ} \mathrm{C}$ for $4 \mathrm{~h}$. They found out that when increasing the time of calcination at this same temperature, there was a gradual conversion from the cubic to the hexagonal phase, which involved a continuous but small loss of oxygen and a gradual increase in the angle from $90^{\circ}$ in the cubic phase to about $90^{\circ} 43^{\prime}$, going through a transient rhombohedral phase until the complete transformation into the hexagonal phase. Thus, the calcined perovskite at $800{ }^{\circ} \mathrm{C}$ is closer to the cubic phase than hexagonal, undergoing transformation to the hexagonal phase with the increase of the calcination temperature and time.

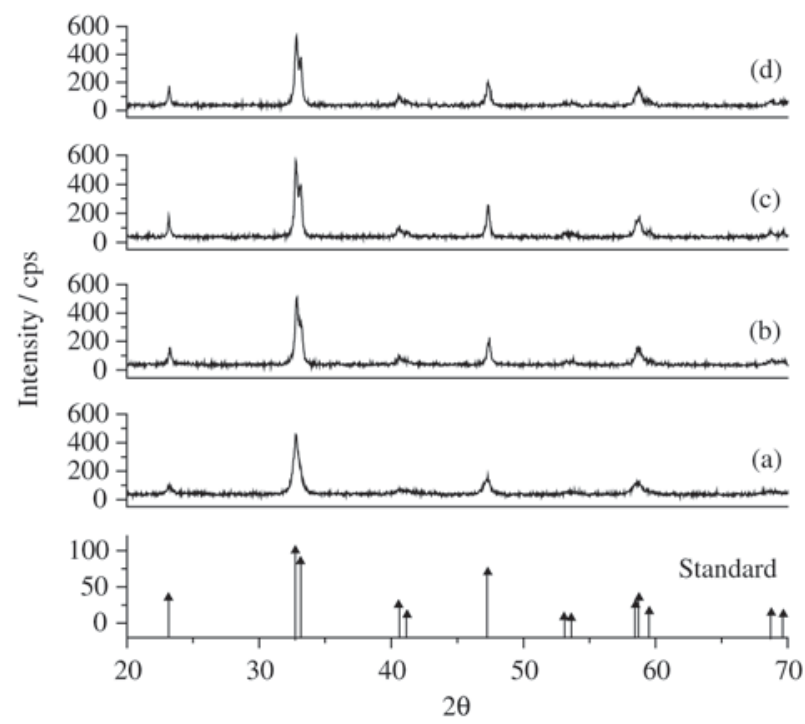

Figure 4. $\mathrm{XRD}$ diagrams of $\mathrm{LaNiO}_{3}$ perovskites calcined at a) $\left.\left.\left.800{ }^{\circ} \mathrm{C}-5 \mathrm{~h}, \mathrm{~b}\right) 900{ }^{\circ} \mathrm{C}-5 \mathrm{~h}, \mathrm{c}\right) 900{ }^{\circ} \mathrm{C}-10 \mathrm{~h}, \mathrm{~d}\right) 900{ }^{\circ} \mathrm{C}-15 \mathrm{~h}$. 
XRD diagrams of the perovskites with partial substitution of $\mathrm{Ni}$ by $\mathrm{Fe}$ and $\mathrm{Co}$ are presented in Fig. 5. In Figure $5 \mathrm{a}$, the XRD shows that the substitution of $\mathrm{Ni}$ for Fe slowly dislocates the diffraction peaks to the left, together with a weak increase of intensity. According to Provendier et al. ${ }^{13}$ this indicates the formation of a solid solution of $\mathrm{LaFeO}_{3}$ and $\mathrm{LaNiO}_{3}$ in all proportions. On the other hand, the addition of $\mathrm{Co}$ (Fig. 5b) to substitute part of $\mathrm{Ni}$ in the perovskite structure results in double peaks in the most intense diffraction position, which would be indicating the formation of a more complex structure, in which $\mathrm{LaNiO}_{3}$ and $\mathrm{LaCoO}_{3}$ coexist.

The DTGA-DTA curves of the precursors are shown in Fig. 6. The measured weight loss percentage for all the oxides was of approximately $40 \%$ at room temperature of up to $625-710{ }^{\circ} \mathrm{C}$. The DTA curves showed the predominance of endothermic transformations. Three peaks were observed at $100-120^{\circ} \mathrm{C}, 420-450{ }^{\circ} \mathrm{C}$ and $590-745^{\circ} \mathrm{C}$ assigned to the removal of hydration water and decomposition of metal nitrates, respectively. The last transformation of the oxides occurs at a maximum temperature of approximately $725^{\circ} \mathrm{C}$ that would be the final rearrange of the oxides, with the formation of the perovskite structure.

Table 2 shows the influence on surface area of the partial substitution of $\mathrm{Ni}$ by $\mathrm{Fe}$ or $\mathrm{Co}$ in the $\mathrm{LaNiO}_{3}$ perovskite prepared by the method 2. In all the samples, except for the calcined at $800{ }^{\circ} \mathrm{C}$, the substitution of $\mathrm{Ni}$ by $\mathrm{Fe}(\mathrm{x}=0.4)$ increased the surface area of the perovskite. It must be noted that the structures that contain $\mathrm{Fe}$ showed less intense variations and different calcination times $(5 \mathrm{~h}, 10 \mathrm{~h}$ and $15 \mathrm{~h}$ ) did not result in greater texture alterations. On the other hand, when the Ni was substituted by Co, the surface area was decreased continuously. When increasing the calcination temperature a significant reduction in the values of surface area occurred, which was more emphasized with the increase of the amount of Co. A similar result was described by Choudhary et al. (1996) ${ }^{1}$. It is also possible to observe that with the increase of the calcination time a decrease of the area also occurs. However, this effect is less intense than the temperature.

Table 2. Surface area of $\mathrm{LaNi}_{(1-x)} \mathrm{Fe}_{\mathrm{x}} \mathrm{O}_{3}$ perovskite oxides.

\begin{tabular}{ccccccc}
\hline Temperature $\left({ }^{\circ} \mathrm{C}\right)^{*}$ & Time $(\mathrm{h})^{*}$ & \multicolumn{5}{c}{ Surface area $\left(\mathrm{m}^{2} \mathrm{~g}^{-1}\right)$} \\
\hline & & $\mathrm{LaNiO}_{3}$ & $\mathrm{LaNi}_{0.6} \mathrm{Fe}_{0.4} \mathrm{O}_{3}$ & $\mathrm{LaNi}_{0.3} \mathrm{Fe}_{0.7} \mathrm{O}_{3}$ & $\mathrm{LaNi}_{0.6} \mathrm{Co}_{0.4} \mathrm{O}_{3}$ & $\mathrm{LaNi}_{0.3} \mathrm{Co}_{0.7} \mathrm{O}_{3}$ \\
900 & 5 & 10.3 & 8.6 & 3.6 & 8.0 & 4.9 \\
900 & 5 & 4.8 & 5.3 & 2.2 & 3.6 & 2.0 \\
900 & 10 & 3.8 & 4.4 & 2.6 & 2.1 & 1.5 \\
900 & 15 & 3.4 & 4.3 & 2.4 & 2.3 & 1.7 \\
\hline
\end{tabular}

* Conditions of calcinations.
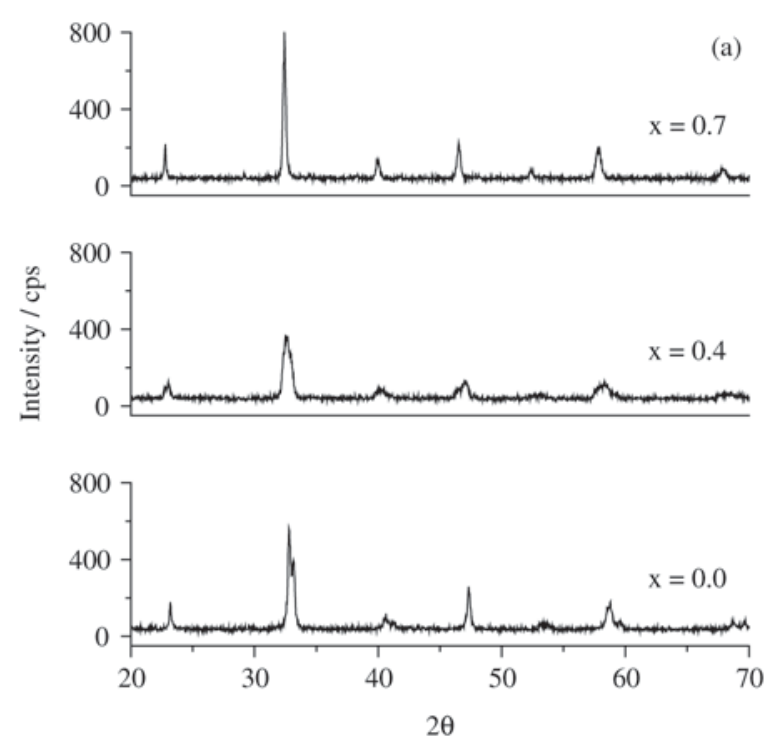
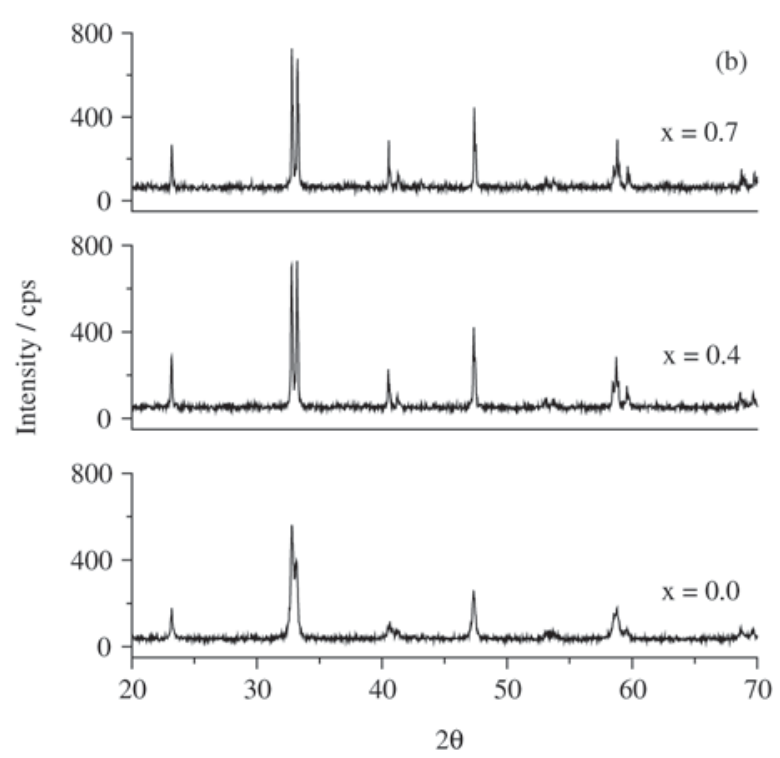

Figure 5. XRD diagrams of perovskites calcined at $900{ }^{\circ} \mathrm{C}$ for $10 \mathrm{~h}$. a) $\mathrm{LaNi}_{(1-\mathrm{x})} \mathrm{Fe}_{\mathrm{x}} \mathrm{O}_{3}$; b) $\mathrm{LaNi}_{(1-\mathrm{x})} \mathrm{Co}_{\mathrm{x}} \mathrm{O}_{3}(\mathrm{x}=0.0,0.4$ and 0.7$)$. 

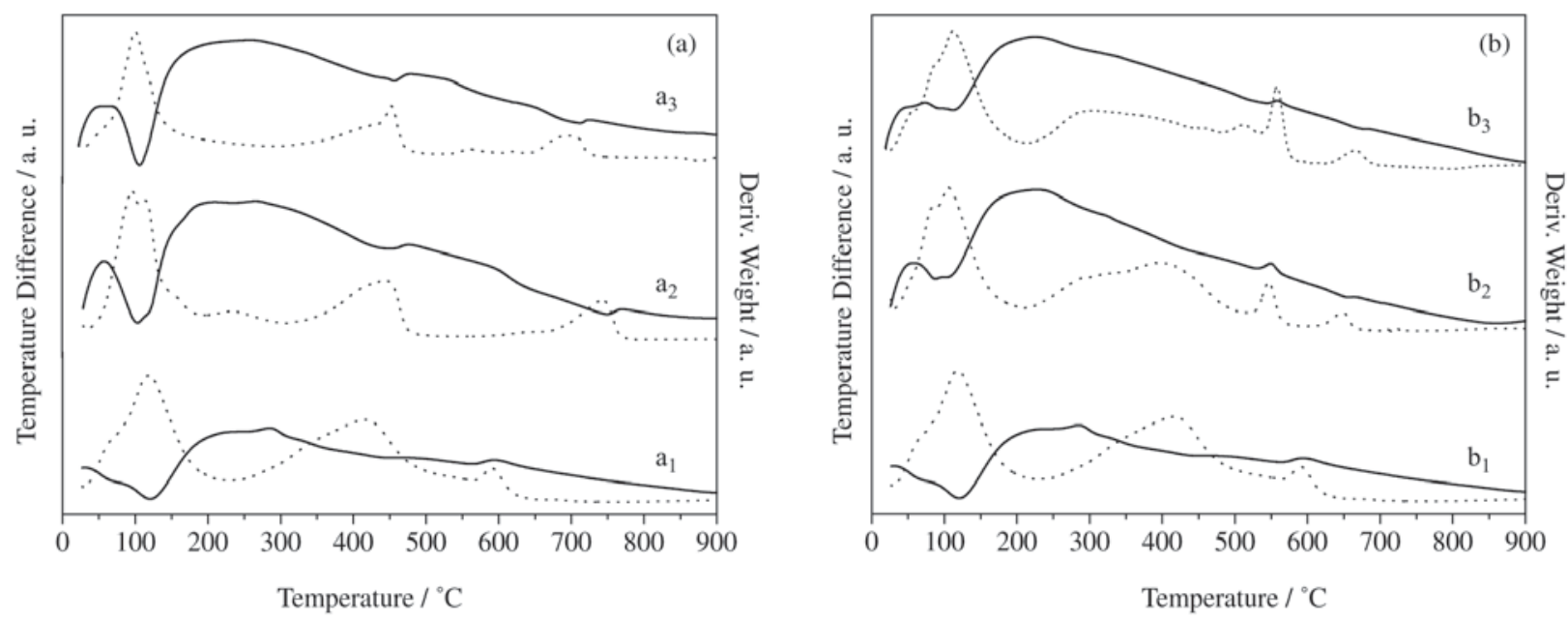

Figure 6. DTGA-DTA curves of the precursors. a) $\left.\mathrm{LaNi}_{(1-\mathrm{x})} \mathrm{Fe}_{\mathrm{x}} \mathrm{O}_{3},\left(\mathrm{a}_{1}\right) \mathrm{x}=0,\left(\mathrm{a}_{2}\right) \mathrm{x}=0.4,\left(\mathrm{a}_{3}\right) \mathrm{x}=0.7 . \mathrm{b}\right) \mathrm{LaNi}_{(1-\mathrm{x})} \mathrm{Co}_{\mathrm{x}} \mathrm{O}_{3},\left(\mathrm{~b}_{1}\right) \mathrm{x}=0,\left(\mathrm{~b}_{2}\right)$ $\mathrm{x}=0.4,\left(\mathrm{~b}_{3}\right) \mathrm{x}=0.7$. [-] DTA; $[\cdots \cdot]$ DTGA.
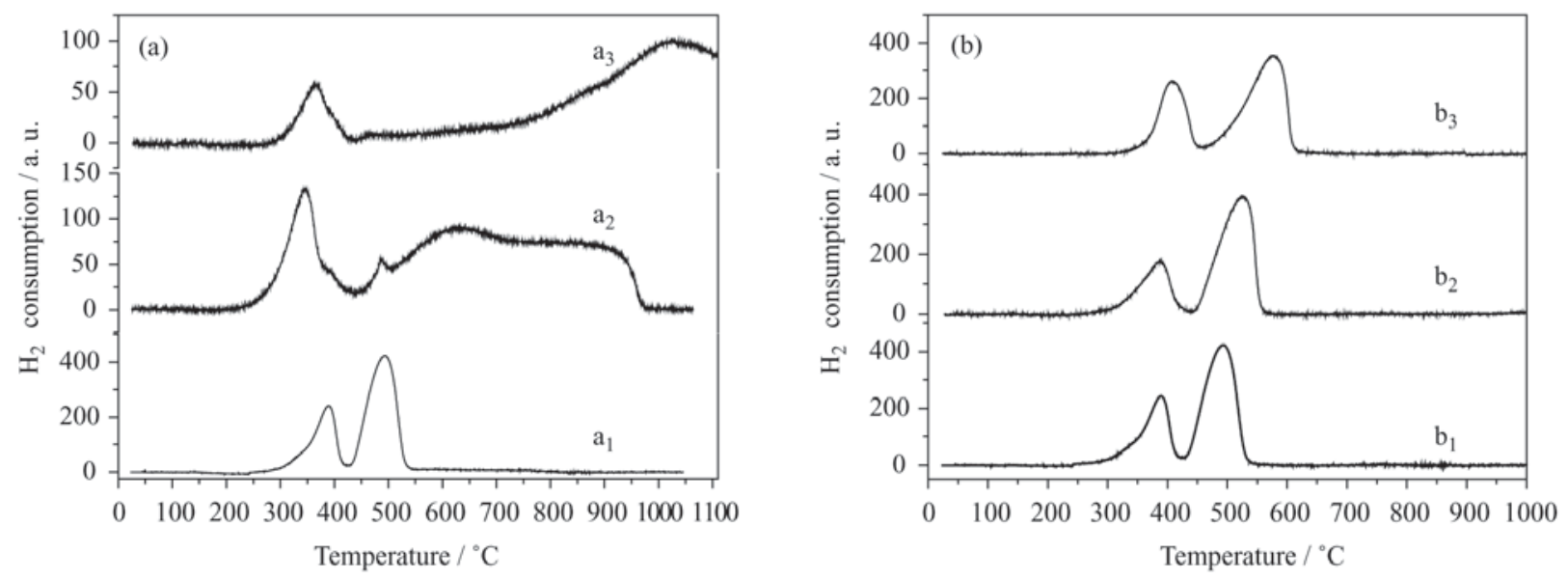

Figure 7. Temperature programmed reduction profiles of perovskites calcined at $900{ }^{\circ} \mathrm{C}$ for 10 h. a) $\mathrm{LaNi}_{(1-x)} \mathrm{Fe}_{\mathrm{x}} \mathrm{O}_{3},\left(\mathrm{a}_{1}\right) \mathrm{x}=0.0,\left(\mathrm{a}_{2}\right)$ $\mathrm{x}=0.4,\left(\mathrm{a}_{3}\right) \mathrm{x}=0.7$. b) $\mathrm{LaNi}_{(1-\mathrm{x})} \mathrm{Co}_{\mathrm{x}} \mathrm{O}_{3},\left(\mathrm{~b}_{1}\right) \mathrm{x}=0.0,\left(\mathrm{~b}_{2}\right) \mathrm{x}=0.4,\left(\mathrm{~b}_{3}\right) \mathrm{x}=0.7$.

Figure 7 shows TPR profiles of the perovskites prepared by method 1 and calcined at $900{ }^{\circ} \mathrm{C}$ for $10 \mathrm{~h}$. The $\mathrm{LaNiO}_{3}$ perovskite presents two reduction peaks (Fig. 7a). The first one, with a maximum at $389{ }^{\circ} \mathrm{C}$ corresponds to the reduction of $\mathrm{Ni}^{3+}$ to $\mathrm{Ni}^{2+}$ with formation of the $\mathrm{La}_{2} \mathrm{Ni}_{2} \mathrm{O}_{5}$ structure. The second peak with a maximum at $493{ }^{\circ} \mathrm{C}$ corresponds to the reduction of $\mathrm{Ni}^{2+}$ to $\mathrm{Ni}^{0}$, which remain deposited on lanthanum oxide. The first reduction peak is similar for all oxides containing nickel, even though the temperature of the maximum hydrogen consumption decreases with an increasing $x$, because the amount of $\mathrm{Ni}$ is decreasing. For $\mathrm{x}=0.4$, a wide band of reduction was observed, with the dislocation of the second peak to the right as a consequence of the formation of a more stable compound. This peak shifts from $493{ }^{\circ} \mathrm{C}\left(\mathrm{LaNiO}_{3}\right)$ up to approximately $1020{ }^{\circ} \mathrm{C}\left(\mathrm{LaNi}_{0.3} \mathrm{Fe}_{0.7} \mathrm{O}_{3}\right)$. According to Provendier et al. ${ }^{13}$ during this second reduction step, the nickel and part of the iron are reduced to metals and form a Ni-Fe alloy. The reduction of $\mathrm{Ni}$ and $\mathrm{Fe}$ has been studied by in situ magnetization and Mössbauer spectroscopy ${ }^{17}$ and these methods confirm the results of TPR.

It must be observed in Fig. $7 \mathrm{~b}$ that the addition of cobalt affect the first reduction peak, with the temperature of maximum hydrogen consumption decreasing with the increase of $x$. The second reduction peak shifts from $493^{\circ} \mathrm{C}\left(\mathrm{LaNiO}_{3}\right)$ up to $578{ }^{\circ} \mathrm{C}(\mathrm{x}=0.7)$, showing that the addition of cobalt has a lower influence in the stability of the nickel when compared to the effect of the addition of the iron. 


\section{Conclusion}

A relatively simple procedure, such as the precipitation method, can result in success if the selective precipitation of the metal oxides other than the perovskite is avoided by choosing the correct way of mixing the salt solutions. At calcination temperatures as low as $800^{\circ} \mathrm{C}$ it was possible to observe the formation of the desired structure, which became slightly more crystalline and closer to the standard phase for higher times and temperatures of calcination. The synthesis of the perovskite oxides at this temperature presents as an advantage, from the point of view of catalysis application, a greater value of specific surface area.

The addition of $\mathrm{Fe}$ and $\mathrm{Co}$ in the $\mathrm{LaNiO}_{3}$ perovskite structure resulted in more stability in reductive atmosphere as showed in the TPR analysis, with prominence for the effect of iron. This larger stability enables the use of these oxides as catalysts in methane reforming reactions at high temperatures and in presence of $\mathrm{H}_{2}$.

\section{References}

1. Choudhary, V.R.; Uphade, B.S.; Belhekar, A.A. Journal of Catalysis, v. 163, p.312-318, 1996.

2. Neumann, B.; Jacob, K. Z. Elektrochem., v. 30, p. 557, 1924.

3. Tsang, S.C.; Claridge, J.B.; Green, M.L.H. Catalysis Today, v. 23, p. 3, 1995.

4. Nam, J.W.; Chae, H.; Lee, S.H.; Jung, H.; Lee, K.Y., Studies in Surface Science and Catalysis: Natural Gas Conversion $V$, v. 119, p. 843-848, 1998.

5. Ruckenstein, E.; Hu, Y.H. Applied Catalysis A: General, v. 133, p.149, 1995.

6. Tang, S.B.; Qiu, F.L.; Lu, S.J. Catalysis Today, v. 24, p.
253, 1995.

7. Horiuchi, T.; Sakuma, K.; Fukui, T.; Kubo, Y.; Osaki, T.; Mori, T. Applied Catalysis A: General, v. 144, p. 111, 1996.

8. Goldwasser, M.R.; Pietri, E.; Barrios, A.; González, O.; Pérez-Zurita, M.J.; Cubeiro, M.L. Actas do XVII Simpósio Ibero-Americano de Catálise, Porto, Portugal, p. 51, julho 2000.

9. Meadowcroft, D.B. Nature, London, v. 226, p. 847, 1970.

10. Voorhoeve, R.J.H.; Remeika, J.P.; Freeland, P.E.; Mathias, B.T. Science, v. 177, p. 353, 1972.

11. Twu, J.; Gallagher, P.K. Properties and Applications of Perovskite-Type Oxides, Marcel Dekker, Inc., p. 1-2, 1993.

12. Swaan, H.M.; Rouanet, R.; Widyananda, P.; Mirodatos, C. Study Surface Science Catalysis, v. 107, p. 107, 1997.

13. Provendier, H.; Petit, C.; Estournès, C.; Libs, S.; Kiennemann, A. Applied Catalysis A: General, v. 180, p. 163-173, 1999.

14. Slagtern, A.; Olsbye, U.; Blom, R.; Dahl, I.M.; Fjellvag, H. Applied Catalysis A: General, v. 145, p. 375, 1996.

15. Slagtern, A.; Olsbye, U.; Blom, R.; Dahl, I.M.; Fjellvag, H. Applied Catalysis A: General, v. 165, p. 379, 1997.

16. Slagtern, A.; Olsbye, U. Applied Catalysis A: General, v. 110, p. 99, 1994.

17. Provendier, H.; Petit, C.; Estournes, C.; Kiennemann, A. Studies in Surface Science and Catalysis: Natural Gas Conversion V, v. 119, p. 741, 1998.

18. JCPDS - Joint Committee on Powder Diffraction Standards, International Center of Diffraction Data, Pensilvania, USA, 1994.

19. Rakshit, S.; Gopalakrishnan, P.S. Journal of Solid State Chemistry, v. 110, p. 28-29, 1994. 